\title{
Die het kleine niet eert ...
}

Citation for published version (APA):

Slaaf, D. W. (1998). Die het kleine niet eert ... Maastricht University. https://doi.org/10.26481/spe.19981009ds

Document status and date:

Published: 09/10/1998

DOI:

$10.26481 /$ spe.19981009ds

Document Version:

Publisher's PDF, also known as Version of record

\section{Please check the document version of this publication:}

- A submitted manuscript is the version of the article upon submission and before peer-review. There can be important differences between the submitted version and the official published version of record.

People interested in the research are advised to contact the author for the final version of the publication, or visit the DOI to the publisher's website.

- The final author version and the galley proof are versions of the publication after peer review.

- The final published version features the final layout of the paper including the volume, issue and page numbers.

Link to publication

\footnotetext{
General rights rights.

- You may freely distribute the URL identifying the publication in the public portal. please follow below link for the End User Agreement:

www.umlib.nl/taverne-license

Take down policy

If you believe that this document breaches copyright please contact us at:

repository@maastrichtuniversity.nl

providing details and we will investigate your claim.
}

Copyright and moral rights for the publications made accessible in the public portal are retained by the authors and/or other copyright owners and it is a condition of accessing publications that users recognise and abide by the legal requirements associated with these

- Users may download and print one copy of any publication from the public portal for the purpose of private study or research.

- You may not further distribute the material or use it for any profit-making activity or commercial gain

If the publication is distributed under the terms of Article $25 \mathrm{fa}$ of the Dutch Copyright Act, indicated by the "Taverne" license above, 


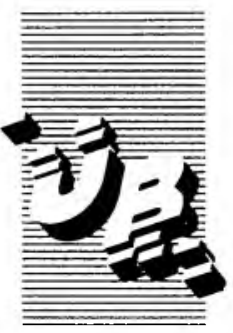

De uitleentermijn verstrijkt op:

Universiteit Maastricht

Postbus 616

6200 MD Maastricht

Gelieve deze publicatie tijdig te retourneren of (telefonisch) verlenging van de uitleentermijn aan te vragen.

UNIVEASITEITSBIBLIOTHEEK UM 


\section{$m G$

\section{Die het kleine niet eert ...}

Rede uitgesproken op vrijdag 9 oktober 1998 bij de aanvaarding van het ambt van bijzonder hoogleraar

Fysica van de Microcirculatie

vanwege de Stichting Wetenschapsbeoefening Universiteit Maastricht op voordracht van het Cardiovasculair Research Instituut Maastricht (CARIM).

Dr. D. W. Slaaf

Die tcleyn niet en voet, en sal nymmermeer tgroot hebben.

Seer schone spreeckwoorden

Antwerpen, 1549 
$3 P 16$ 15y y2y 019

Universitertsobblióliciét'

Universiteit Maastrich 
Mijnheer de Rector Magnificus,

Leden van het Bestuur van de Universiteit,

Leden van het Bestuur van de Stichting Wetenschapsbeoefening

Universiteit Maastricht,

Leden van het Bestuur van de Faculteit der Geneeskunde,

Leden van het Bestuur van het Onderzoekinstituut CARIM,

Zeer geachte dames en heren,

Bij het horen van mijn leeropdracht, "Fysica (of natuurkunde) van de Microcirculatie", zal niet iedereen een duidelijk beeld hebben van de inhoud ervan. Tijdens mijn rede zal ik $u$ inzicht proberen te geven in dit vakgebied en de richting waarin mijn onderzoeksinteresse gaat. Een aantal facetten van de microcirculatie geven mij aanleiding om een vergelijking te maken met verschijnselen uit het gewone leven, soms serieus, soms wat minder serieus. Op de achtergrond zullen dia's en videobeelden voor ondersteuning van mijn woorden zorgen, meestal zonder dat ik ze specifiek zal bespreken.

Het onderzoek naar bouw en functie van de microcirculatie begon kort nadat Harvey begin zeventiende eeuw aannam dat het bloed in het lichaam kon circuleren. Het onderzoek kende van tijd tot tijd korte oplevingen, maar pas in het begin van deze eeuw kwam de ontwikkeling echt op gang. Voor die tijd werd de voortgang vooral beperkt doordat er geen meetmethodes beschikbaar waren om functionele studies te verrichten. Men beperkte zich voornamelijk tot het bewonderen van elkaars microscoopbeelden. De interactie van natuurkundigen en 
ingenieurs met fysiologen en clinici heeft voor de uiteindelijke doorbraak gezorgd.

\section{Circulatie}

Wanneer men in de dikke Van Dale de betekenis van het woord circulatie opzoekt, vindt men onder andere als verklaring: omloop, kringloop in het bijzonder van bloed en geld. Waar het circuleren van geld al in de oudheid bekend was, is de kennis dat bloed circuleert van veel recentere datum. In 1628 werd de circulatie voor het eerst beschreven door de Engelsman Wiliam Harvey. Hij volgde systematisch de loop van het bloed in het lichaam en kwam tot de conclusie dat het bloed circuleert als gevolg van het samentrekken van het hart. De bloedsomloop kan onderverdeeld worden in de circulatie in de grote en de kleine bloedvaten, of met andere woorden in de macrocirculatie en de microcirculatie. De macrocirculatie heeft een transportfunctie en kan vergeleken worden met grote rivieren en kanalen. De microcirculatie zorgt voor uitwisseling tussen bloed en weefsel en is zo geordend dat de afstand tussen bloed en weefsel klein genoeg is voor een goede voeding van het weefsel. Daarmee lijkt de microcirculatie op het kanalen- en slotenstelsel in de Nederlandse polders.

Wanneer bloedvaten van de macrocirculatie niet goed functioneren, kan door een juiste instelling van de achterliggende microcirculatie vaak toch nog de benodigde doorbloeding van een orgaan bewerkstelligd worden. Andersom kan bij een normaal functionerende macrocirculatie toch van een slechte doorbloeding van het weefsel sprake zijn als de microcirculatie verstoord is. De microcirculatie speelt dus een belangrijke rol in de doorbloeding van een orgaan. 
Om het circuleren te kunnen verklaren veronderstelde Harvey de aanwezigheid van porositates in carne, ofwel gaten in het vlees. Tussen de kleine slagaders en aders zouden kanaaltjes in het weefsel moeten lopen. Deze kanaaltjes in het weefsel waren echter te klein om begin zeventiende eeuw waargenomen te kunnen worden.

\section{Microscopie}

Beschrijving van de microcirculatie begint rond het midden van de 17 e eeuw dankzij de uitvinding van de microscoop. Hoewel tal van wetten van de optica al ver voor het begin van onze jaartelling door Grieken en Romeinen aangetoond waren, duurde het tot de late middeleeuwen voordat er echt met lenzen werd gewerkt om oogatwijkingen te corrigeren of om voorwerpen te vergroten. Op een schilderij van Raphael uit 1518 staat paus Leo $X$ afgebeeld met een vergrootglas in zijn hand. De telescoop en de microscoop werden ongeveer gelijktijdig uitgevonden. De Nederlanders Hans Jansen en zijn zoon zouden tussen 1590 en 1612 als eersten lenzen gecombineerd hebben om tot grotere vergrotingen te komen. Daar waar de astronomen vrijwel direct begonnen met het toepassen van telescopie voor hun onderzoek, werd er met de microscoop vrijwel geen serieus onderzoek gedaan. De basis voor een verdere ontwikkeling van de microscoop werd gelegd door natuurkundigen die probeerden te begrijpen op welke manier een beeld door een lenzenstelsel gevormd wordt. De belangstelling voor de microscoop nam pas toe rond 1650 .

De gelukkige combinatie van instrumentmakers die microscopen gingen vervaardigen en de groeiende tendens om het functioneren van 
mens en dier mechanisch te beschrijven, leidde ertoe dat men de gaten in het vlees uit de circulatietheorie van Harvey ging zoeken. Het was de Italiaan Marcello Malpighi die in 1661 als eerste de kanaaltjes in het vlees waarnam. In de wand van een opgeblazen en vervolgens gedroogde long van een kikker nam Malpighi met zijn microscoop tal van kleine bloedvaten waar. De naam van deze minuscule bloedvaten, capillairen of haarvaten, is afgeleid van hun gelijkenis met een haar, in het Italiaans capillo.

Onze landgenoot Antoni van Leeuwenhoek, die leefde van 1632 tot 1723 , deed al zijn microscopische waarnemingen met enkelvoudige microscopen, die hij zelf bouwde. Volgens zijn tijdgenoot Hooke was het gebruik van een dergelijke microscoop - eigenlijk een loep bestaande uit een lensje met een doorsnede van slechts één millimeter - bepaald niet comfortabel. Van Leeuwenhoek heeft talloze waarnemingen gedaan aan levende weefsels. Tot zijn belangrijkste ontdekkingen behoren bacteriën en zaaddiertjes. Op het gebied van de microcirculatie bestaat zijn bijdrage onder andere uit het aantonen van het bestaan van rode bloedcellen. Verder was hij de eerste die de snelheid heeft gemeten waarmee het bloed door capillairen stroomt.

Van Leeuwenhoek had geen enkele vorming op natuurwetenschappelijk gebied. Hij stuurde zijn waarnemingen in briefvorm in het Nederlands aan de Royal Society in Londen. Er is nooit een samenhangend werk van zijn bevindingen gepubliceerd. Publicaties zijn beperkt gebleven tot het uitgeven van zijn brieven in het Nederlands en vertalingen in het Latijn, Frans en Duits. Het grote voordeel van zijn gebrekkige vooropleiding was dat hij daardoor niet geremd werd door verkeerde ideeën en ook, in tegenstelling tot zovele van zijn en onze tijdgenoten, geen behoefte had om 
waarnemingen achter te houden wanneer zij niet strookten met de gangbare theorie.

Van de $18 \mathrm{e}$ tot de $19 \mathrm{e}$ eeuw was het hebben van een microscoop een modeverschijnsel. In die tijd werden de microscopen wel steeds verbeterd, hetgeen betekende dat aan het einde van de $19 \mathrm{e}$ eeuw microscopen gecorrigeerd waren voor kleurafwijkingen en mechanisch goed te bedienen. $\mathrm{Na}$ de eerste wereldoorlog werden instrumenten, waaronder de microscoop, in snel tempo vervaardigd. Deze eeuw heeft de studie van de microcirculatie in toenemende mate aandacht gekregen door het beschikbaar komen van goed bruikbare meetmethoden en videotechnieken om microscoopbeelden op te kunnen slaan.

\section{Het onderzoek}

In 1976 werd een begin gemaakt met het microcirculatie-onderzoek aan de Faculteit der Geneeskunde in Maastricht als onderdeel van het onderzoekprogramma Hart- en Vaatziekten. Op dat moment waren alle ingrediënten aanwezig voor een succesvolle start: een creatieve fysioloog die een fysiologische vraagstelling formuleerde vanuit een klinisch probleem; instrumentmakers en een electronicus om apparatuur aan te passen aan de specifieke eisen van het microcirculatie-onderzoek; videoapparatuur voor de registratie van de microscoopbeelden van de microcirculatie, waardoor de waarnemingen later geanalyseerd konden worden; een natuurkundige voor kwantitatieve en methodologische aspecten. Kortom een multidisciplinair team onderzoekers dat al snel uitgebreid werd. 


\section{Microcirculatie}

Ik zal een korte beschrijving geven van de microcirculatie. De microvaten zijn structureel en functioneel onderdeel van het orgaan waarin ze zijn gelegen en zijn dan ook aangepast aan de specifieke eisen van dat orgaan. Kleine slagaders vormen de toegang tot de microcirculatie van een weefsel. De aanvoerende bloedvaten in de microcirculatie, de slagadertjes of arteriolen, hebben een diameter van minder dan drietiende van een millimeter en vertakken zich in steeds kleinere vaten. De bloedstroom wordt voortdurend gesplitst om op die manier de vele netwerken van capillairen te voeden. De kleine slagadertjes reguleren de doorbloeding van het achterliggende vaatbed. Ze passen hun diameter aan door de gladde spiercellen in de vaatwand te laten samentrekken of te ontspannen. Ze zijn bekleed met endotheelcellen. De kleinste bloedvaten, de capillairen of haarvaten, hebben een diameter van 4-10 duizendsten van een millimeter en een dunne wand bestaande uit endotheelcellen. De diameter van een capillair in een skeletspier is kleiner dan de diameter van een onvervormde rode bloedcel. Tijdens de passage van het capillairbed moeten rode bloedcellen zich voortdurend vervormen. De vaten die het bloed uit de capillairen afvoeren heten de kleine adertjes of venules. De overgang van capillair naar venule gaat geleidelijk. Steeds meer venules stromen samen tot ze uiteindelijk uitmonden in de grote aders.

De snelheid in de circulatie neemt steeds meer af naarmate het bloed verder van het hart af geraakt. In de aorta van de mens is de snelheid waarmee het bloed stroomt ongeveer 1 meter per seconde bij een dwarsdoorsnede van het vat van ongeveer 2,5 vierkante centimeter. Op het niveau van de capillairen is de stroomsnelheid van het bloed 
gedaald tot ongeveer drietiende millimeter per seconde. De lagere snelheid is het gevolg van het grote aantal capillairen in de microcirculatie. Een eenvoudige berekening leert dat dit betekent dat er zo'n 70 miljard capillairen in het menselijk lichaam aanwezig zijn. Elk capillair verzorgt gemiddeld een miljoenste gram weefsel.

\section{Doorbloedingsregulatie en ritmes}

De doorbloeding van een skeletspier in rust, maar ook die van de huid van de mens, is nogal dynamisch. Er vinden voortdurende versnellingen en vertragingen van de stroomsnelheid van het bloed plaats. Zoals men bij microscopische waarneming van de microcirculatie direct kan zien, zijn deze snelheidsvariaties voor een deel gerelateerd aan het veranderen van de diameter van de aanvoerende slagadertjes. Deze spontane ritmische vaatwandbewegingen noemen we vasomotion. Het was in de wetenschappelijke literatuur gebruikelijk om ook de snelheidsveranderingen, zoals die in capillairen waargenomen werden vasomotion te noemen. De snelheidsveranderingen zijn weliswaar het gevolg van de vaatwandbewegingen, maar zijn daarmee natuurlijk zelf geen vasomotion. Als natuurkundige vond ik het niet juist om een waarneming te noemen naar een achterliggend fenomeen en niet de waarneming als zodanig te benoemen. De term die ik koos voor de ritmische snelheidsveranderingen, flowmotion ofwel stromingsbeweging, is feitelijk dubbelop, maar is nu toch algemeen in de literatuur opgenomen.

Vasomotion en flowmotion vinden hun oorsprong in cyclische, zich herhalende processen. Veel processen in het lichaam zijn cyclisch, elk met een eigen ritme. Op het moment dat verschillende van deze cyclische 
processen met elkaar in interactie komen, worden de resultaten ervan bij elkaar opgeteld. Nu is voor dergelijke processen één en één niet altijd twee. De cyclische processen kunnen elkaar extra versterken of extra verzwakken. We noemen dit niet-lineaire processen. In de microcirculatie kunnen diameter- en snelheidsveranderingen onverwachte patronen vertonen en er als het ware chaotisch uitzien. Chaos wordt meestal gezien als een staat van ongeordendheid, maar vaak ligt er toch een beperkt aantal cyclische processen aan ten grondslag. Het feit dat we de voortgang ervan niet goed kunnen voorspellen is het gevolg van het feit dat we niet precies weten wat de situatie op een bepaald moment is. Het probleem is hetzelfde als dat van de weersvoorspellers. Hoewel overal op de wereld waarnemingen gedaan worden in vele weerstations en er dus een vrij complete weerkaart voorhanden is, kunnen kleine meetfouten of veranderingen evvoor zorgen dat een weersvoorspelling dramatisch anders uitvalt. Zoals Lorenz -de grondlegger van de moderne weersvoorspelling - eens stelde, kan het gaan vliegen door een vlinder in San Francisco in feite beslissen over het al dan niet ontstaan van een tornado in het Caribisch gebied. In niet-lineaire systemen kunnen kleine gebeurtenissen dus onverwacht grote gevolgen hebben. Voor het bestuderen van dit soort processen zijn moderne wiskundige methodes nodig. In relatie tot veel fysische en chemische problemen is die wiskunde al ontwikkeld, terwijl ze al veel wordt toegepast in de cardiologie. Voor het microcirculatie-onderzoek ligt de beperking meer in berekeningstechnische problemen en gebrek aan op de juiste manier verkregen gegevens. Nu er steeds meer geschikte methodes ter beschikking komen, kan het bestuderen van diameter- en snelheidvariaties in de microcirculatie ons waarschijnlijk veel leren omtrent de staat waarin het systeem zich bevindt. 
Het is gebruikelijk in de medische wetenschap te spreken over homeostase: het bestaan van onderling op elkaar afgestemde processen die de voor het functioneren noodzakelijke toestanden constant houden. Het begrip homeostase lijkt oppervlakkig gezien juist. We hebben echter al gezien dat doorbloeding nogal aan schommelingen onderhevig is en binnen een orgaan op kleine afstand van elkaar zeer sterk verschillend kan zijn. Deze twee waarnemingen zijn niet direct in overeenstemming met een zeer nauwkeurige regulatie. Een regelmatige hartslag blijkt bij nauwkeurige waarneming ook niet zeer regelmatig en daarmee constant te zijn. Het is juist het optreden van kleine afwijkingen in het hartritme dat aangeeft dat het systeem nog vitaal is. Een goed dynamisch systeem is relatief losjes georganiseerd. Het systeem moet slechts binnen zekere grenzen blijven in plaats van op één bepaalde plaats. In een dergelijk dynamisch systeem is er op allerlei plaatsen ruimte voor een eigen dynamiek. In een strak gereguleerd systeem dat alles precies ordent, gaat alle energie zitten in het handhaven van de precies gewenste toestand. Homeostase naar de letter lijkt enigszins op een strak geleide communistische maatschappij. Het menselijk lichaam functioneert gelukkig met meer dynamiek, weliswaar met een bepaalde hiërarchie, maar er bestaan toch veel vrijheden. De regulatie in het lichaam lijkt meer op een kapitalistische maatschappij waarbij men met een beperkt aantal regels veel vrijheden heeft zolang het totaal zich maar binnen zekere grenzen beweegt. Om het dynamische karakter van het evenwicht in het lichaam beter weer te geven zou men niet langer over homeostase moeten spreken, maar over homeokinese. 


\section{Vaatbedstructuren}

In de natuur groeien planten en bloemen volgens een beperkt aantal wetmatigheden of regels. Ook de bloedvaten in de microcirculatie worden waarschijnlijk aangelegd volgens een beperkt aantal regels. Modelstudies hebben aangetoond dat een beperkt aantal regels -volgens welke bloedvaten zich vormen- voldoende is om met behulp van een computer realistische vaatbomen te kunnen genereren voor allerlei weefsels. Deze regels hangen nauw samen met de functie van het orgaan en de daarmee samenhangende signaalfuncties. Voor de groei of het achterblijven ervan, zijn stoffen van belang die de vaatgroei mede reguleren. Door omstandigheden kunnen die stoffen teveel of te weinig aanwezig zijn. Dit zal een gevolg hebben voor de vorm van de vaatboom, en daarmee voor de kwaliteit van de microcirculatie. Al vele jaren wordt in Maastricht vanuit farmacologisch-klinische belangstelling onderzoek verricht waarin de kwaliteit en organisatie van de microcirculatie een belangrijke rol spelen. Daarvoor wordt het chorio-allantois membraan van het kippenei gebruikt. Dit membraan vervult dezelfde functie als de placenta voor zoogdieren. In een klein stukje van dat weefsel kan de ontwikkeling van de bloedvaten farmacologisch gemanipuleerd worden en kan het groeiproces op opeenvolgende dagen in detail bestudeerd worden.

In het groeiende membraan kan men de door Harvey veronderstelde gaten in het vlees in een oervorm waarnemen. De rode bloedcellen lopen als het ware willekeurig door het weefsel tussen de aan- en afvoerende vaten. De gaten zijn een voorstadium van de capillairen; tijdens de groei wordt een deel van de gaten omgevormd tot capillairen doordat endotheelcellen buisjes gaan vormen. 
De normale ontwikkeling van een vaatboom en de veranderingen die daarin op kunnen treden onder invloed van allerlei ziekteprocessen hangen samen met het veranderen van de spelregels van groei en ontwikkeling. Hierdoor leent dit onderzoek zich uitermate voor een fysische benadering. In samenwerking met Dr. Ferdinand Le Noble, die zich op het vakgebied van vorming van nieuwe bloedvaten gespecialiseerd heeft, zal met behulp van moleculairbiologische- en fluorescentietechnieken het groeiproces gemanipuleerd en geanalyseerd worden.

\section{Glijden}

Bloedcellen lijken met groot gemak door de capillairen te glijden. Uit het dagelijks leven weten we dat de aanwezigheid van een dunne laag van een bepaalde samenstelling bepaalt hoe glad een oppervlak is en hoe gemakkelijk je er over glijdt.

Schaatsen is glijden over ijs. Waarom een schaats met zo weinig wrijving over ijs kan glijden is lange tijd onderwerp van speculaties geweest. De meest gangbare theorie was dat door de druk van de schaats er een dun laagje water op het ijs werd gedooid, waarop de schaats zou glijden. Berekeningen leerden echter dat de voor dit proces beschikbare tijd niet toereikend is. Recent onderzoek heeft aangetoond dat op ijs steeds een dun laagje watermoleculen aanwezig is dat voor de lage glijweerstand zorgt. De dikte van dit laagje is afhankelijk van de temperatuur.

Ook het bestaan van een grenslaageffect in de microcirculatie is lange tijd onderwerp van speculaties geweest. Rode bloedcellen glijden 
schijnbaar moeiteloos door nauwe capillairen. Ze kunnen gemakkelijk vervormen en in de andere richting gaan stromen. Nauwkeurige bestudering van de afmetingen van capillairen en rode bloedcellen bracht aan het licht dat er te weinig rode bloedcellen in het capillair aanwezig waren. Dit kon niet door meetfouten verklaard worden, maar wel door aan te nemen dat er een dun laagje moleculen op de wand van het capillair aanwezig was, waardoor de vloeistof in die laag niet aan de doorstroming mee kon doen. Inmiddels is aangetoond dat er een dunne laag glycocalix aanwezig is op de endotheelcellen die enige tienduizendsten van een millimeter dik is en daarmee een niet verwaarloosbaar deel van de $d$ warsdoorsnede van een capillair beslaat. Bepaalde eigenschappen van de glycocalix bepalen of er bij lage bloedstroomsnelheden nog wel rode bloedcellen door een capillair zullen stromen. De rode bloedcellen volgen de weg van de minste weerstand en mijden de moeilijk toegankelijke wegen. Hierdoor zien we in sommige capillairen relatief veel en in andere capillairen relatief weinig rode bloedcellen.

\section{Interacties van de vaatwand met bloedcellen}

De endotheelcellen aan de binnenzijde van bloedvaten zijn niet slechts een bekleding van de vaatwand en een barrière naar het weefsel, maar hebben tevens een belangrijke signaleringsfunctie. Zo zijn deze cellen in staat om de door het stromende bloed op de cellen uitgeoefende kracht te voelen, als het ware te meten. Op basis daarvan communiceren zij met de omringende gladde spiercellen die voor de mate van contractie van het bloedvat zorgen en daarmee voor de mate van doorstroming. Deze zogenaamde transductie van de op de endotheelcel uitgeoefende kracht vormt de basis van een van de vele regelkringen voor de 
doorstroming van het bloedvat. Een andere belangrijke functie van het endotheel is de interactie met circulerende stoffen, die centraal of lokaal geproduceerd worden en vaatverwijdende of vaatvernauwende effecten hebben. Deze signalen worden ook vertaald voor de gladde spiercellen. De aard van de signalen die het endotheel doorgeeft, is sterk afhankelijk van de plaats waar de endotheelcellen zich in de vaatboom bevinden.

Endotheelcellen spelen ook een belangrijke rol bij het recruteren van witte bloedcellen uit de bloedstroom om ze vervolgens in het weefsel te laten dringen. Onder normale omstandigheden stromen de witte bloedcellen op enige afstand langs het endotheel en zijn ze nauwelijks te onderscheiden van de langsstromende rode bloedcellen. Wanneer we naar de microcirculatie in de kleine afvoerende adertjes kijken, dan valt op dat we met enige regelmaat witte bloedcellen zien rollen langs de vaatwand. Het is juist in deze vaten dat bij ontstekingsreacties de witte bloedcellen door de vaatwand heen in het weefsel dringen om daar hun herstelwerkzaamheden te verrichten. Het is als met het stempelen tijdens een Elfstedentocht. $\mathrm{Er}$ is een aantal vooraf gemerkte plaatsen waar deze interactie tussen de langsglijdende deelnemers en de stempelpost moet plaatsvinden. Een interressante vraag is natuurlijk hoe een witte bloedcel weet waar de interactieplaatsen zich bevinden en welke formaliteiten daar afgewikkeld dienen te worden. In het laboratorium voor microcirculatie wordt onder leiding van Dr. Mirjam oude Egbrink onderzoek verricht naar de processen die een rol spelen bij het rollen van witte bloedcellen. Via farmacologische methodes worden de samenstellende elementen bestudeerd van de opeenvolgende reacties die een rol spelen bij het rollen van de witte bloedcellen. 
Een belangrijke hulptechniek bij microcirculatie-onderzoek is het merken van cellen of delen ervan met fluorescerende stoffen. Bij een juiste manier van verlichten zien we in de microscoop de structuren waar de fluorescerende stoffen zich aan gehecht hebben oplichten. Door het merken worden deze structuren als het ware lichten in de duisternis. Het is tegenwoordig mogelijk om allerlei receptoren op de endotheelcellen te merken met fluorescerende stoffen. Daardoor kunnen we waarnemen waar deze receptoren precies gelokaliseerd zijn. We kunnen ze ook afschermen en bestuderen of daarmee het rollen van de witte bloedcellen verandert. Een paar jaar geleden heeft het Instituut CARIM een fluorescentie afbeeldingssysteem verworven om in levend weefsel met hoge gevoeligheid en nauwkeurigheid fluorescentie te meten. Een van de uitdagingen zal zijn om deze techniek voor het zojuist beschreven onderzoek in onze preparaten toe te passen.

\section{lonconcentraties}

Bij vele processen in de microcirculatie spelen lokale concentraties en verplaatsingen van ionen een belangrijke rol. Er bestaan fluorescerende stoffen waarvan de intensiteit varieert met de concentratie van bepaalde ionen. Door de intensiteit van de fluorescentie te meten, kunnen we de relatieve concentratie van zo'n ion bepalen en daarmee ook de eventuele verplaatsing. Van bijzonder belang zijn die fluorescerende stoffen die niet slechts bij één golflengte licht uitstralen, maar bij twee verschillende golflengtes. Een prettige eigenschap van die fluorescerende stoffen is dat bij deze stoffen door verandering van een ionconcentratie de intensiteit bij de ene golflengte bijvoorbeeld afneemt, terwijl de intensiteit bij de andere golflengte juist toeneemt. Door nu de verhouding tussen de 
intensiteiten bij de twee golflengtes te bepalen, kunnen we dus de concentratie van het ion bepalen. Deze methode is veel minder afhankelijk van allerlei externe factoren die de meting kunnen beïnvloeden. Ze wordt al veelvuldig toegepast in geïsoleerde bloedvaten en in gekweekte endotheelcellen. Toepassing in het intacte levende weefsel is een stuk lastiger. Het al eerder genoemde fluorescentie afbeeldingssysteem zal het ons mogelijk gaan maken deze methode routinematig toe te passen voor ons werk in levende weefsels. We hopen daarmee meer te leren van de mechanismes die de door ons waargenomen veranderingen veroorzaken.

\section{Klinisch microcirculatie-onderzoek}

Het feit dat ik in mijn oratie niet uitgebreid inga op microcirculatieonderzoek bij patiënten ligt zeker niet aan een gebrek aan belangstelling daarvoor. Het tegendeel is waar. De beperkte spreektijd heeft mij echter gedwongen een keuze te maken uit een aantal mogelijke onderwerpen. Eén opmerking wil ik wel maken. Van Leeuwenhoek was waarschijnlijk de eerste die klinisch microcirculatie-onderzoek deed. Het viel hem op dat wanneer hij behoorlijk ziek was, zijn bloedglobulen, zoals hij de rode bloedcellen noemde, hard en stijf leken, terwijl ze zachter en flexibeler werden wanneer hij weer gezond werd. Hedentendage is het meten van de vervormbaarheid varı rode bloedcellen een belangrijke methode om de oorzaak van een aantal ziektes te verklaren. 
18 


\section{Onderzoekorganisatie, integraal management}

In de circulatie mogen lokale eenheden, de organen, hun eigen perfusiebeleid bepalen, zolang de functie die het orgaan uit moet oefenen ten behoeve van het hele systeem, het lichaam, maar adequaat uitgevoerd wordt. Het lokale perfusiebeleid moet goed zijn voor het orgaan en geen overdreven nadelige gevolgen hebben voor het functioneren van het totale systeem. Hier wordt als het ware een model van integraal management toegepast. In principe zijn alle mogelijkheden om het orgaan te laten functioneren aanwezig en heeft het orgaan de mogelijkheden om te meten en te regelen. Welke perfusieregulatie het orgaan precies toepast hangt af van zijn functies. Hoewel er voortdurend sprake is van een beperkte invloed van het centrale niveau, zal er pas ingegrepen worden als één van de vooraf bekende vitale functies in gevaar komt. Bepaalde organen zullen dan sterk in hun doorbloeding beperkt worden ten gunste van de meest vitale functies. Hieruit zou een overheid of bestuur moeten concluderen dat slechts bij hoge uitzondering in het onderzoekbeleid van een onderzoekinstituut ingegrepen zou moeten worden. Het tegendeel is vaak het geval.

De laatste 15-20 jaren is de Nederlandse regering erin geslaagd om het Nederlandse onderzoek voortdurend te laten reorganiseren, verder in te perken en te reguleren. Academische vrijheid werd in toenemende mate beperkt. In diezelfde periode heeft het universitaire onderzoek gekozen voor een andere, grootschaliger organisatievorm: instituten en onderzoekscholen ontstonden. Daarmee is een betere onderlinge samenhang van het onderzoek en de bijbehorende opleiding tot onderzoeker gegarandeerd. Instituten dienen te kunnen functioneren als 
de organen in een lichaam. Wanneer de doelstellingen van een instituut helder geformuleerd zijn en vervolgens ook regelmatig geëvalueerd worden, zal een systeem van instituten en onderzoekscholen met een grote mate van autonomiteit uitstekend werken. Pas bij dysfunctioneren van een instituut of bij belangrijke keuzes die het belang van een instituut te boven gaan, zou onder invloed van centraal gestuurde aanwijzingen de ingezette koers gewijzigd dienen te worden. Naar analogie met het microcirculatiemodel dient een instituut een grote mate van vrijheid te hebben voor de interne organisatie en moet het de middelen, financieel en ondersteunend, krijgen om de doelstellingen op een eigen manier te verwezenlijken.

Op het niveau van een orgaan bestaan vele signaleringsmechanismen. Niet alleen de druk in bloedvaten en de snelheid van het bloed, maar ook de hoeveelheid zuurstof in het bloed bij het verlaten van individuele capillairen spelen bij de regulatie van de doorbloeding een rol. Passen we dit systeem van signalering toe op het management van onderzoek binnen de hoofdlijnen van onderzoek van een instituut, dan betekent dit dat niet alleen de leiding van het onderzoek via de aanvoer van middelen en faciliteiten een belangrijke rol moet spelen, maar ook dat feedback door de individuele onderzoeker in het veld van vitaal belang is. Bij te sterke sturing aan de ingang kan immers geen rekening gehouden worden met de grote heterogeniteit van het onderzoek en zullen specifieke vragen inherent aan bepaalde soorten van onderzoek niet gehonoreerd worden. Dit leidt net als in de microcirculatie tot lokale ondervoeding en daarmee tot het verdwijnen van belangrijke functies. 


\section{Onderwijs}

Onderwijs moet, research mag? Dit gevoel dat menig medewerker af en toe bekruipt, impliceert dat onderwijs het stiefkind zou zijn van de universiteit. En toch weten we allemaal dat door veel medewerkers met veel plezier onderwijs gegeven wordt. De geconstateerde tegenstelling is een schijnbare. Ze werd echter wel bijna werkelijkheid doordat in administratieve zin de Faculteit der Geneeskunde tot nu toe slechts onderwijs binnen het medisch curriculum als onderwijs erkende. Hierdoor konden sommige medewerkers nauwelijks aan officieel onderwijs geven toe komen. Geen gebrek aan willen, maar meer het niet kunnen speelde mijns inziens de belangrijkste rol. Uit de inbreng die het vakgebied Fysica van de Microcirculatie mijns inziens in onderwijs kan hebben, zal blijken dat mijn kijk op onderwijs breder is.

Kennis verwerven door problemen op te lossen en de veelheid van aspecten van de gepresenteerde problemen in directe samenhang bestuderen, vormen de kern van het onderwijs aan de Faculteit der Geneeskunde in Maastricht. Zelfstudie en onderwijsgroepen staan daarbij centraal. Bij deze aanpak is er niet altijd plaats voor een directe inbreng van alle basisvakken. Dit is tot nu toe zeker nadelig geweest voor de vakgroep Biofysica, waarbij de leerstoel Fysica van de Microcirculatie is ondergebracht. Recent zijn er echter nieuwe mogelijkheden ontstaan om de erkende onderwijshorizon te verbreden: sinds vorig jaar bestaat er onderwijsvraag vanuit de nieuwe studierichting Biomedische Technologie die de Universiteit Maastricht samen met de Technische Universiteit Eindhoven verzorgt. De Faculteit der Geneeskunde heeft op deze nieuwe situatie verstandig ingespeeld door het onderwijs net als het onderzoek in 
een instituut onder te brengen. Onderwijsvraag en -aanbod kunnen binnen dat instituut beter op elkaar afgestemd worden dan binnen de verschillende capaciteitsgroepen. Ik spreek hierbij de hoop uit dat onze onderwijsorganisatie, die tot nu toe kwantitatief zeer detaillistisch ingesteld is, in staat zal blijken te zijn om dit probleem met zijn vele vrijheidsgraden adeqaat op te lossen.

Zoals ik al eerder heb betoogd, speelt de microcirculatie een belangrijke rol in het functioneren van de verschillende organen van de mens. Daarom is een goed begrip van de microcirculatie van groot belang voor de medisch student. Het bestuderen van de microcirculatie komt op dit moment in het medisch curriculum al regelmatig aan bod. Regulatie, signalering en activatie van allerlei processen worden op het niveau van de kleinste bloedvaten bestudeerd. Het functioneren van de microcirculatie kan ook ruimschoots aan bod komen binnen de opleiding Biomedische Technologie. Daarbij zullen niet alleen meetmethoden en hun technische onderbouwing een belangrijke rol spelen, maar ook het functioneren van organen en de bijbehorende regulatiemechanismen.

Elementen van het vakgebied Fysica van de Microcirculatie die zich uitstekend lenen voor het onderwijs binnen de eerder door mij genoemde studierichtingen zijn:

- het kennis maken met microscopie als een methode om kleine structuren waar te nemen. Naast het leren bedienen van de microscoop dient ook de fysische achtergrond aan bod te komen waarom de handeling het waargenomen effect heeft.

- in het onlangs goedgekeurde practicumplan van de Faculteit der Geneeskunde is een practicum Microcirculatie opgenomen. Fysische 
principes zullen aan de fysiologische werkelijkheid gerelateerd worden en omgekeerd.

- studenten van de Faculteit der Geneeskunde en van de Faculteit Gezondheidswetenschappen kunnen wetenschapsstages volgen in het laboratorium voor Microcirculatie.

- rond regelmechanismen van de microcirculatie is een casus gemaakt voor het tweede jaar van de opleiding Biomedische Technologie. - optische meettechnieken vormen een belangrijk onderwerp binnen de opleiding Biomedische Technologie. In het tweede studiejaar zal een bijdrage geleverd worden aan een collegecyclus over dit onderwerp. - in de afstudeerfase van de studie Biomedische Technologie zullen studenten gedurende langere tijd in het laboratorium voor Microcirculatie werkzaam zijn.

- verder wordt er een bijdrage geleverd aan de cursus "Metingen in de Biomedische Wetenschappen" voor assistenten in opleiding binnen het onderzoekinstituut CARIM.

Ook met de instelling van het onderwijsinstituut wordt in het Maastrichtse niet al het onderwijs administratief als onderwijs gezien. Een groot deel van het onderwijs voltrekt zich binnen de gekwalificeerde onderzoekstijd. De begeleidings- en opleidingsaspecten van die assistenten in opleiding, waarvoor men directe verantwoordelijkheid heeft, worden mogelijk terecht tot het onderzoek gerekend. Echter het programmatisch $\mathrm{AlO}$-onderwijs binnen instituten zou tot het reguliere onderwijs gerekend moeten worden. Nu de inzet van medewerkers steeds meer een afweging tussen leidingen van onderzoek- en onderwijsinstituten wordt, zal dit onderscheid hopenlijk van minder belang worden en een eigen erkenning verwerven. 


\section{Waarom?}

De vraag is gerechtvaardigd, waarom wetenschappers het allemaal doen. Professor Csikszentmihalyi geeft een mij aansprekend antwoord op die vraag: flow, doorstroming, een begrip dat sterk gekoppeld is aan mijn onderzoek. Volgens Csikszentmihalyi is een basis voor het menselijk welzijn gelegen in de ervaring van geconcentreerd werken aan een taak die de volle aandacht vasthoudt. Zo'n taak kan een flowervaring oproepen, een gevoel van welbevinden. Wel moet er evenwicht zijn tussen de capaciteiten van een persoon en de eisen die de taak aan die persoon stelt. Dit verklaart waarom welbevinden gelegen kan zijn in laat doorwerken of veel trainen voor een sportief doel. Niet omdat het op dat moment zo leuk is, zoals Pavlov's theorie aangeeft, maar omdat het past in het zelfbeeld. Het meten van dit soort flow zal mogelijk een belangrijk instrument worden in het hedentendage zo belangrijke Human Resource Management.

In de NRC las ik een aantal maanden geleden een stelling van de vroegere voorzitter van de Universiteit van Amsterdam, wijlen Jankarel Gevers, over de menstypen die door de verschillende vakken aangetrokken worden. De socioloog Gevers zag er een patroon in. Sociologen hebben altijd bonje en economen kunnen heel slecht met hun eigen begroting omgaan. Natuurkundigen kunnen volgens Gevers zichzelf besturen. Misschien komt dat wel door goede flowregulatie; kennelijk worden de capaciteiten van natuurkundigen en de taak die bestuurlijk vervuld wordt goed op elkaar afgestemd. 
Die het kleine niet eert, is het grote niet weerd

In mijn voordracht heb ik de microcirculatie steeds gedetailleerder besproken; van de algemene microcirculatie tot de rol van ionen. Wie geen oog heeft voor het kleine, de verschillende details, zal niet tot het juiste inzicht komen omtrent het grote, het functioneren van de micro- en macrocirculatie. Wie zich echter verliest in de details treft hetzelfde lot. 


\section{Dankwoord}

Mijnheer de Rector Magnificus, leden van het College van Bestuur, leden van het bestuur van CARIM. I $k$ wil $u$ bedanken voor het vertrouwen dat $u$ in mij stelt blijkens mijn benoeming tot bijzonder hoogeraar. Ik wil ook de Faculteit der Geneeskunde en de Stichting Wetenschapsbeoefening Universiteit Maastricht voor hun bijdrage daarin bedanken.

Dames en heren, het mag u duidelijk zijn dat een wetenschappelijke carrière tal van inspiratiebronnen kent. Ik wil allen die mij geïnspireerd hebben van harte bedanken. Een aantal wil ik apart memoreren.

Allereerst wil ik mijn ouders bedanken voor het feit dat zij mij gestimuleerd hebben om een goede opleiding te volgen en mij daarbij toch de ruimte hebben gelaten om van het studentenleven te genieten. Mijn vader heeft helaas slechts een korte tijd van mijn wetenschappelijke carrière kunnen meemaken. Ik zie hem nog genieten tijdens het feest na mijn promotie. Ik hoop dat genieten vanavond bij mijn moeder te kunnen zien.

Het pad als onderzoeker ben ik tijdens mijn studie experimentele natuurkunde ingeslagen aan de hand van Dr. Siegenbeek van Heukelom. Beste Jan, ik ben je zeer erkentelijk voor de waardevolle trainingen die ik tijdens mijn studie in meerdere opzichten van je gehad heb.

Tijdens mijn promotie-onderzoek in Rijswijk kreeg ik onder leiding van Dr. E. Meeter, Dr. W.F. Stevens en mijn promotor Prof. Dr. D. de 
Wied voor het eerst echt te maken met multidisciplinair onderzoek. In meerdere opzichten was deze combinatie een lot uit de loterij.

In 1975 ben ik samen met Prof. Dr. R.S. Reneman begonnen aan het avontuur van het microcirculatie-onderzoek. Beste Rob, ik ben je dankbaar voor je visie op de kansen voor dit toendertijd voor Nederland nieuwe onderzoek. Het is een vruchtbare lijn geworden, niet op zijn minst dankzij jouw diepgaand inzicht. Jij bracht mij ook in contact met waardevolle buitenlandse leermeesters als Harold Wayland, Curt Wiederhielm en Jim Bassingthwaighte. Daarnaast was je een goede reisgezel en hebben we samen veel plezier beleefd aan het organiseren van congressen.

In de afgelopen 22 jaren hebben vele promovendi het laboratorium voor microcirculatie bemensd. Samen met hen heb ik het genoegen gehad zeer verschillende onderzoeksrichtingen te kunnen exploreren. De promovendi waren afkomstig uit de capaciteitsgroepen Algemene Heelkunde, Biofysica, Farmacologie, Fysiologie, Immunologie, Inwendige Geneeskunde, Kindergeneeskunde en Oogheelkunde. Deze 8 verschillende groepen representeren de breedte van het onderzoeksveld microcirculatie en van mijn eigen belangstelling. Twee promovendi zijn mij voorgegaan op de weg naar het hoogleraarschap. Hooggeleerden Tangelder en Jacobs, beste Geert-Jan en Michael. Ik ben jullie dankbaar voor de vruchtbare samenwerking die wij gehad hebben.

Vroeger heette het niet-wetenschappelijk personeel, tegenwoordig ondersteunend en beherend personeel. Ik prefereer de laatste naamgeving, maar hoe ze in de toekomst ook mogen heten, ze zijn de kurk waar een laboratorium op drijft. Ik prijs mij gelukkig met het feit dat Rinus 
Alewijnse en Sabrina van Velzen die functies in het laboratorium voor microcirculatie zo lang en zo goed vervuld hebben.

De laatste jaren bevolkten vele studenten het laboratorium. Ik wil hen bedanken voor hun vaak naïve en daarmee stimulerende inbreng.

Mijn collega's in de capaciteitsgroep Biofysica zijn voor mij een goede steun geweest. Ik wil daarbij speciaal vermelden dat ik in de loop der jaren dankzij twee voortreffelijke secretaresses, Rosy Hanssen en Lucienne van Haarlem, mijn vele taken heb kunnen combineren.

Ik stelde al eerder de vraag: waarom? Daar zou ik aan toe willen voegen: waardoor? Jeannette, Eelco en Saskia zijn, ieder op hun eigen wijze, mij tot grote steun geweest, iets dat ik door mijn drukke bezigheden niet altijd voor hen geweest ben. Ik stel de interactie met hun totaal verschillende niet exact geörienteerde talenten zeer op prijs.

Ik heb gezegd. 